\title{
VIEWPOINTS
}

\section{The Significance of Hijrah in Islam}

\author{
Mohammad Hashim Kamali*
}

Hijrah, migration or exodus, initially of the Prophet Muhammad and his companions from Mecca to Yathrib (later renamed Madinah), features prominently in the Qur'an and the teachings and Sunnah of the Prophet himself. The Prophet and his followers migrated, after thirteen years of campaign in Mecca on 1 Rabi' al-Awwal/13 September 622 AD, arriving in Yathrib 11 days later on 24 September. The commemoration of the Hijri calendar was instituted, however, seventeen years later by the second caliph, 'Umar ibn al-Khattab (r. 634-644). The new calendar dates from the first day of the first lunar month of the year, that is, Awwal Muharram. Although 'Umar instituted the official era, the custom of referring to events and happenings to before or after the Hijrah originated with the Prophet himself.

Hijrah in the early history of Islam is also discussed in conjunction with the migration of a group of Muslims from Mecca to Abyssinia in $615 \mathrm{AD}$. They were subjected to persistent persecution by the pagans of Mecca so much so that the Prophet advised them to seek asylum in Ethiopia where they could live in peace under the Christian emperor Negus. They migrated and stayed in Ethiopia until time was right for them to join the Prophet in Madinah. Although migration to Ethiopia was voluntary and limited in scope, the one to Madinah was obligatory and involved the entire Muslim community. No Muslim was supposed to stay behind except for the very weak, women, children and the sick, who could not afford to travel the $270 \mathrm{~km}$ distance to Madinah.

The word hijrah in the Qur'an is used in the sense of departure, abandonment or boycott, usually implying the idea of abandonment physically or mentally, of an existing undesirable state for something better. The Prophet's migration to Madinah played a decisive role in consolidating the unity of the nascent community of Muslims, not only in their faith in Islam but also in the physical sense of exodus to a new destination. That hijrah moved the centre stage of events in the early history of Islam from Mecca to Madinah and marked a turning point in the eventual success of Islam. It was also a test of devotion to Islam, indicating a willingness to endure all suffering caused by the movement to a new locale for the sake of protecting one's life and faith (Qur'an, 3:195; 4:100). 
The emigrants had to leave behind their homes, friends, family and belongings. To take a challenge of that kind was an act of faith that demanded strength of conviction. It is in this light that hijrah was made into an obligation and no longer a mere expression of individual freedom. Many Muslim scholars also reached the conclusion that hijrah was advisable, even from Islamic lands, if it meant escape from an environment of oppression, denial of freedom of conscience, and indulgence in sin.

The major message of hijrah is one of transformation, both inner and outer, for Muslims in the context both of religion and exit physically from unacceptable conditions, just as it also meant a symbolic refusal to lose hope in the face of persecution. The moral of hijrah is that religious persecution is a violation of religious freedom (Qur'an, 2:218; 4:97).

Hijrah has also impacted the language and style of the Qur'an and the manner how Muslims were to relate with other communities and nations. The psychologically intense tone of the Qur'anic engagement with the idolators of Mecca began to change, after the Prophet's migration, to a more serene tone of language and discourse. In terms of content and subject matter, the Qur'anic messages began to evolve, from an initial focus on the essentials of belief and monotheism, worship and morality, to legal rules that regulated the various aspects of life in the new environment. Another manifestation of hijrah in the Qur'an is that all of its 114 suras bear the designation, whether of Makki or of Madini origin, which has in turn juridical consequences for understanding the occasions of revelation (asbab al-nuzul) of its various verses, and the more contentious phenomenon of abrogation (naskh) therein.

Muslims have also interpreted the hijrah in various other ways. They often imbued with symbolism and validation of their various interpretations of the religion. In Sufi literature, for instance, the hijrah is considered an important stage in the inner spiritual journey of returning to one's Creator and abandonment also of attachment to one's worldly and material belongings. Enduring the physical hardships of hijrah is viewed as a process of self-purification for the love of God.

Various religious and political movements in Africa and Asia in the pre-andpost colonial times have, furthermore, employed hijrah as a major theme of their movements. Hijrah was, thus, seen to be closely associated with jihad as those who migrate in the way of God also engage in a holy struggle and true meaning of jihad. An emigrant is described as one who abandons sin and also associating with habitual sinners. This was taken further by one Qur'an commentator, Sayyid Qutb (d. 1966), for instance, to urge his readers to dissociate themselves from corrupt society, a controversial linkage that was subsequently taken by such radical groups as that of al-jihad wa'l-hijrah to draw some of their unwarranted conclusions. 
Hijrah features in numerous hadiths, in one of which it has been linked with repentance (tawbah), which is itself a major theme of Islam. Thus, the hadith that "migration will not end until repentance ends and repentance will not end until the sun rises in the west." The parallel between migration and repentance here visualises the mental or psychological dimension of hijrah in the sense that both signify a mental departure from a certain state of mind toward a fresh resolve for self-renewal, transformation and reform.

\section{Note}

* Mohammad Hashim Kamali, Founding Chairman and CEO of IAIS Malaysia, graduated from Kabul University, and took his $\mathrm{PhD}$ in Islamic and Middle Eastern Law at the University of London in 1969. Professor Dr M.H. Kamali served as Professor of Islamic Law and Jurisprudence at the International Islamic University Malaysia (IIUM, 1985-2007), then Dean of the International Institute of Islamic Thought and Civilization (ISTAC). He also held Visiting Professorships at McGill University's Institute of Islamic Studies; Capital University, Ohio; and the Wissenschaftskolleg, Berlin. A member of the Constitution Review Commission of Afghanistan (2003), he has provided expert legal consultation to the new constitutions of Iraq, the Maldives and Somalia. Eminent authority on Islamic legal studies, he has published over 150 academic articles and 35 texts, including standard textbooks at universities worldwide. 